University of Nebraska - Lincoln

DigitalCommons@University of Nebraska - Lincoln

Differences in Habitat Use by Blanding's Turtles, Emydoidea blandingii, and Painted Turtles, Chysemys picta, in the Nebraska Sandhills

\author{
R. Bruce Bury \\ California State University - Bakersfield \\ David J. Germano \\ California State University - Bakersfield
}

Follow this and additional works at: https://digitalcommons.unl.edu/usgsstaffpub

Part of the Earth Sciences Commons

Bury, R. Bruce and Germano, David J., "Differences in Habitat Use by Blanding's Turtles, Emydoidea blandingii, and Painted Turtles, Chysemys picta, in the Nebraska Sandhills" (2003). USGS Staff -Published Research. 148.

https://digitalcommons.unl.edu/usgsstaffpub/148

This Article is brought to you for free and open access by the US Geological Survey at DigitalCommons@University of Nebraska - Lincoln. It has been accepted for inclusion in USGS Staff -- Published Research by an authorized administrator of DigitalCommons@University of Nebraska - Lincoln. 


\title{
Differences in Habitat Use by Blanding's Turtles, Emydoidea blandingii, and Painted Turtles, Chysemys picta, in the Nebraska Sandhills
}

\begin{abstract}
We sampled a variety of wetlands in the Nebraska sandhills at Valentine National Wildlife Refuge. Significantly more individuals of painted turtles (Chrysemys picta) occurred in lakes and open waters than in marshes or small ponds, and the opposite was true for Blanding's turtles (Emydoidea blandingii). Besides this marked difference in habitat use, $46 \%$ of the captured E. blandingii in pond/marsh habitat were juveniles, but only $31.6 \%$ in lakes and open water. Current information suggests that marshes and small ponds are important habitat for juvenile turtles, especially Emydoidea blandingii.
\end{abstract}

\section{INTRODUCTION}

The Nebraska sandhills are open grassland on stabilized rolling dunes, but also contain many marshes, ponds and large lakes (Bleed and Flowerday, 1990). The sandhills are home to five species of freshwater turtles (Hudson, 1972), including two emydids: the Blanding's turtle (Emydoidea blandingii) and painted turtle (Chrysemys picta). Emydoidea blandingii has a patchy distribution across a latitudinally compressed range extending from Nova Scotia and New York through the Great Lakes region to western Nebraska (McCoy, 1973; Mockford et al., 1999). There is growing concern about the conservation status of E. blandingii prompted by substantial habitat loss and fragmentation leading to population declines (Kofron and Shreiber, 1985; Condgon et al., 2000). In contrast, C. picta is widely distributed throughout much of North America and occurs in all of the Great Plains from Oklahoma northward (Ernst, 1971). It is usually the most abundant turtle in suitable shallow water bodies within its range (Ernst et al., 1994).

Understanding habitat use is important for the conservation and management of turtles, especially for hatchlings and juveniles that are highly vulnerable to predation and other losses. However, few or no juvenile Emydoidea blandingii have been found during ecological studies (see Gibbons, 1968; Graham and Doyle, 1977; Ross, 1989; Rowe, 1992). This lack of recruitment has been proposed as a major threat to the survival of E. blandingii (Congdon et al., 1993).

Pappas and Brecke (1992) stated that information concerning the ecology of juvenile Emydoidea blandingii is virtually nonexistent. Unlike prior studies, however, they captured a relatively large number of juveniles $(\mathrm{n}=95)$ in Minnesota during a 4-y study and reported that these small-sized turtles selected shallow vegetated waters. They suggested that this habitat offered young turtles refuge from predators as well as foraging sites that may reduce intraspecific competition with larger turtles in deeper waters.

Our objectives were to determine the occurrence and habitat use of freshwater turtles in a range of wetland habitats in western Nebraska. We specifically compare how juvenile and adult Emydoidea blandingii and Chrysemys picta use different types of wetlands. Lastly, we examine the importance of small wetlands to the conservation of freshwater turtles.

\section{MethoDS}

The study site was Valentine National Wildlife Refuge (NWR), Cherry County, Nebraska (Long. $100^{\circ} 5^{\prime} \mathrm{W}$, Lat. $\left.42^{\circ} 5^{\prime} \mathrm{N}\right)$. This is a large reserve with low grazing pressure from livestock and no agriculture. Some waters are managed to increase duck production, but most are natural wetlands in a sparsely inhabited region. We studied turtles in June-July 1991 and April 1992. Most captures occurred 13-20 July 1991 in a range of habitats from large lakes to marshes. We set traps in vegetated shallows or at the interface of aquatic vegetation and open water in lakes ( $>5$ ha open water) and ponds/marshes ( $<1$ ha open water). We used two types of traps in about equal proportion: commercial hoop traps made of nylon-mesh $(\mathrm{ca} .25 \mathrm{~mm}$ ) with $0.75 \mathrm{~m}$ diameter metal frames and one funnel opening and box traps $(0.35 \mathrm{~m}$ square by $0.85 \mathrm{~m}$ long) that we constructed using $2.5 \mathrm{~cm}$ poultry wire with a funnel opening at each end (modified from Iverson, 1979). Traps were baited with canned sardines and checked twice per day (early morning and late afternoon). Most traps were set in late afternoon, left for two nights and pulled the morning of the third day. We define 1 trap night (TN) as a set of a trap from evening to the next morning. Most trap nights $(70.9 \%)$ were in lakes. 
TABLE 1.-Study sites, water sizes, trap effort and 1991-1992 captures of Chelydra serpentina, Chrysemys picta and Emydoidea blandingii from two different habitat types at Valentine National Wildlife Refuge, Nebraska. TN is the number of trap nights

\begin{tabular}{lccccc}
\hline \hline \multicolumn{1}{c}{ Habitat type } & Estimated size (ha) & TN & Chelydra & Chrysemys & Emydoidea \\
\hline Large open water ( $>5$ ha) & & & & & \\
$\quad$ Pelican Lake & 327 & 24 & 0 & 3 & 2 \\
Hackberry Lake & 279 & 51 & 2 & 17 & 5 \\
Dewey Lake & 226 & 54 & 2 & 4 & 1 \\
Pony Lake & 70 & 24 & 0 & 0 & 0 \\
West Long Lake & 25 & 24 & 0 & 0 & 2 \\
Homestead Lake & 24 & 24 & 0 & 19 & 2 \\
Little Hay Lake & 7 & 0 & 1 & 0 \\
Subtotal & & 4 & 44 & 12 \\
& & & & & \\
Small ponds (<1 ha)/Marshes & 0.5 & 4 & 0 & 0 & 1 \\
Pond N of Hackberry Lake & 0.5 (each) & 32 & 0 & 1 & 12 \\
Ponds (3) E of Dewey Lake & 0 & 48 & 1 & 4 & 35 \\
Hay Valley Marsh & & 84 & 1 & 5 & 48 \\
Subtotal & & & &
\end{tabular}

Further, colleagues caught 16 Emydoidea blandingii during a faunal survey of the refuge in June 1991 and these were preserved as voucher specimens (Germano et al., 2000). Three were captured on roads and excluded here; the other 13 were trapped in large lakes (Dewey, Pelican, and Hackberry). We also found 10 shells of recently dead E. blandingii on the shore of two small adjacent ponds that were $>1 \mathrm{~km}$ from other bodies of water. No trap effort was recorded or possible for these specimens and dead turtles, and they were excluded from comparisons of yield (number/TN).

\section{Results AND Discussion}

We caught 114 turtles in 289 trap nights of sampling. The number of turtles differed in the two habitat types: lakes and ponds/marshes (Table 1). We only captured 5 common snapping turtles (Chelydra serpentina) and there were too few to show any pattern. Chrysemys picta were captured in $71.4 \%$ of the sampled lakes but only $33.3 \%$ of the ponds/marshes and Emydoidea blandingii were in $71.4 \%$ of lake sites and $100 \%$ of the ponds/marshes.

There were significant differences between the number of Chrysemys picta and Emydoidea blandingii in the types of habitats (Heterogeneity $X^{2}=49.9, \mathrm{df}=1, \mathrm{P}<0.001$ ). We found 44 C. picta in lake habitat but only 5 in ponds/marshes, which is a significant difference $\left(X^{2}=30.42, \mathrm{df}=1, \mathrm{P}<0.001\right)$. The frequency of captures was 0.20 turtles per trap night in lakes and $0.05 / \mathrm{TN}$ in ponds/marshes. There also was a significant difference in habitat use of E. blandingii, but opposite that of C. picta, with $12 E$. blandingii caught in lakes and 48 in ponds / marshes $\left(X^{2}=20.16, \mathrm{df}=1, \mathrm{P}<0.001\right)$. There was the same disparity in captures with 0.06 turtles/TN in lakes and $0.57 / \mathrm{TN}$ in ponds/marshes.

The proportions of adults and juveniles differed in the two types of habitats (Fig. 1). Of 77 Emydoidea blandingii trapped or found as shells, and for which we have sex and age data (excludes 6 turtles captured in 1992 in lakes), 36.3\% were males, $31.6 \%$ were females and $31.6 \%$ were juveniles in lake habitat $(\mathrm{n}=19)$. In pond/marsh habitats, males accounted for $29.3 \%$, females $25.9 \%$ and juveniles $44.8 \%$ of the captures $(\mathrm{n}=58)$. Also, $75.9 \%$ of turtles in pond/marsh habitat could be assigned an age $(\leqslant 16 \mathrm{y})$ and of these, $12.1 \%$ were $\leqslant 5$ y (Fig. 1). In lake habitat we could estimate age of only $63.2 \%$ of captured turtles, and only one $(5.3 \%)$ was $\leqslant 5 \mathrm{y}$.

Although we trapped turtles in lakes with over twice the effort than ponds/marshes, we caught only $20 \%$ of the Emydoidea blandingii $(\mathrm{n}=12)$ in lakes and $80 \%(\mathrm{n}=48)$ in the pond/marsh habitat. 

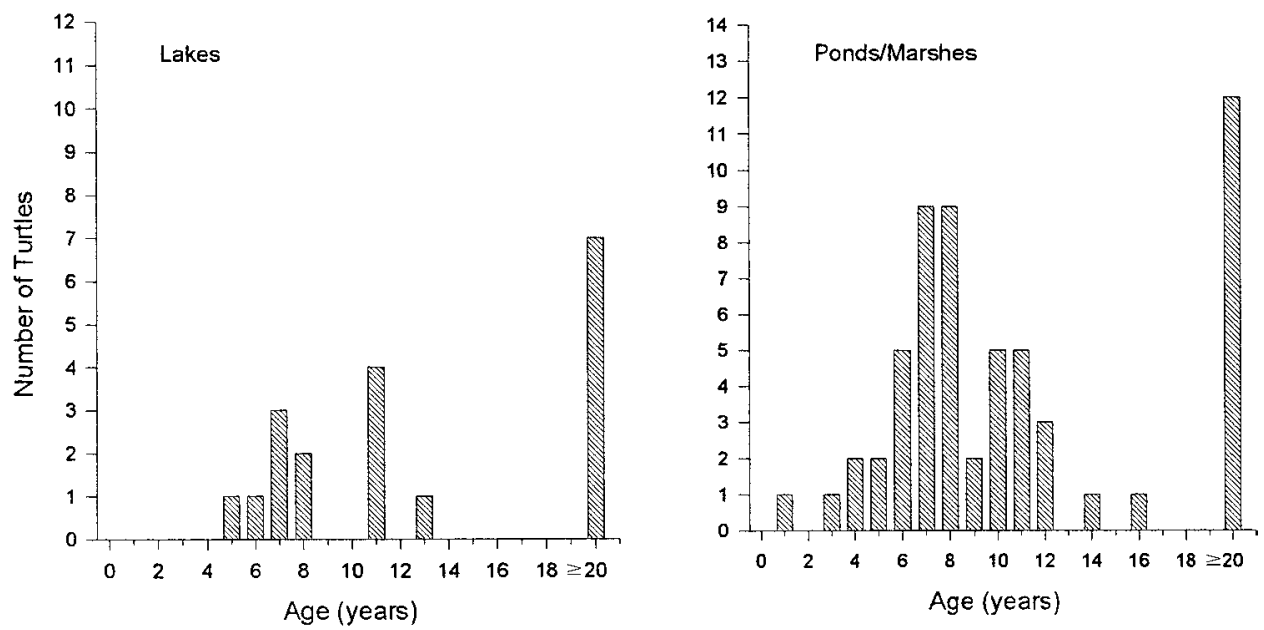

Fig. 1.-Distribution of ages of Blanding's turtles (Emydoidea blandingii) captured in lake (left) and pond/marsh habitats (right) in western Nebraska

Proportions of Chrysemys picta in these habitats were the opposite with almost all (91\%) occurring in lakes. Further, $46 \%$ of the captured E. blandingii were juveniles in pond/marsh habitat. Pappas and Brecke (1992) also found that the smallest juvenile E. blandingii they caught were more often in shallower, more vegetated water than in open water.

Ross and Anderson (1990) found that 8 adult Emydoidea blandingii radio-tagged in Wisconsin spent proportionally more time in ponds than in marshes based on the amount of habitat available. They did not define the sizes of these water bodies. We found more adult $E$. blandingii in marshes and small ponds than in lakes at Valentine National Wildlife Refuge. Our evidence suggests that juvenile and adult E. blandingii prefer small ponds and marshes, but some adults also use edges of larger lakes in Nebraska. The shallow waters and dense vegetation of small ponds and marshes likely provide more cover for young E. blandingii than lakes, which have a high proportion of open water and predators such as large fish.

We need to better define the ecology of hatchling and young turtles, and what factors limit their occurrence to shallow waters until they reach a body size that affords better protection from predators. Current information suggests that marshes and small waters are critically important areas for young turtles as they may be home to the majority of juvenile stages for species like Emydoidea blandingii. We suggest that these small waters receive more management attention and protection. Lastly, we need to focus efforts to better sample juvenile turtles, which are often neglected in turtle life history and ecology studies.

Acknowledgments.-We thank Len McDaniels of Valentine NWR for his assistance and vast knowledge of the Nebraska sandhills. We appreciate the able field help of Mary E. Jennings and Michael J. Adams. Field was part of an integrated biological survey of Valentine and Fort Niobara NWRs and we thank Michael Bogan of USGS for the opportunity to participate in this project. Field work was funded by the U.S. Fish and Wildlife Service.

\section{Literature Cited}

Bleed, A. and C. Flowerday (eds). 1990. An Atlas of the Sand Hills. Conservation and Survey Division, Institute of Agriculture and Natural Resources, University of Nebraska-Lincoln. Resource Atlas No. 5a. 265 p.

Congdon, J. D., A. E. Dunham and R. C. van Loben Sels. 1993. Delayed sexual maturity and demographics of Blanding's turtle (Emydoidea blandingii): implications for conservation and management of long-lived organisms. Cons. Biol., 7:826-833. 
R. N. Nagle, O. M. Kinney, M. Osentoski, H. W. Avery, R. C. van Loben Sels and D. W. Tinkle. 2000. Nesting ecology and embryo mortality: implications for hatching success and demography of Blanding's turtle (Emydoidea blandingii). Chelonian Cons. Biol., 3:569-579.

Ernst, C. H. 1971. Chrysemys picta. Cat. Am. Amphib. Reptiles, 106:1-4.

, J. E. Lovich and R. W. Barbour. 1994. Turtles of the United States and Canada. Smithsonian Institution Press, Washington, D.C. 578 p.

Germano, D. J., R. B. Bury and M. Jennings. 2000. Growth and population structure of Emydoidea blandingii from western Nebraska. Chelonian Cons. Biol., 3:618-625.

Gibbons, J. W. 1968. Observations on the ecology and population dynamics of the Blanding's turtle, Emydoidea blandingi. Can. J. Zool., 46:288-290.

Graham, T. E. And T. S. Doyle. 1977. Growth and population characteristics of Blanding's turtles, Emydoidea blandingii, in Massachusetts. Herpetologica, 33:410-414.

Hudson, G. E. 1972. The amphibians and reptiles of Nebraska. Nebraska Cons. Bull., 24:1-146.

Iverson, J. B. 1979. Another inexpensive turtle trap. Herpetol. Rev., 10:55.

Kofron, C. P. AND A. A. Schrieber. 1985. Ecology of two endangered aquatic turtles in Missouri: Kinosternon flavescens and Emydoidea blandingii. J. Herpetol., 19:27-40.

McCoy, C. J. 1973. Emydoidea, E. blandingii. Cat. Am. Amphib. Reptiles, 136:1-4.

Mockford, S. W., M. Snyder and T. B. Herman. 1999. A preliminary examination of genetic variation in a peripheral population of Blanding's turtle, Emydoidea blandingii. Mol. Ecol., 8:323-327.

Pappas, M. AND B. J. BRecke. 1992. Habitat selection of juvenile Blanding's turtles, Emydoidea blandingii. J. Herpetol., 26:233-234.

Ross, D. A. 1989. Population ecology of painted and Blanding's turtles (Chrysemys picta and Emydoidea blandingi) in central Wisconsin. Wisconsin Acad. Sci., Arts, Let., 77:77-85.

- AND R. K. ANDERSON. 1990. Habitat use, movements, and nesting of Emydoidea blandingi in central Wiscosin. J. Herpetol., 24:6-12.

Rowe, J. W. 1992. Observations of body size, growth, and reproduction in Blanding's turtle (Emydoidea blandingii) from western Nebraska. Can. J. Zool., 70:1690-1695.

R. BRUCE BURY ${ }^{1}$, USGS Forest and Rangeland Ecosystem Science Center, 3200 SW Jefferson Way, Corvallis, Oregan 97331 AND DAVID J. GERMANO, Department of Biology, California State University, Bakersfield 93311. Submitted 8 October 2001; accepted 19 July 2002.

${ }^{1}$ e-mail: Bruce_Bury@usgs.gov 